\title{
The Effect of Reward System And Information Technology on Relationship Between TQM Implementation And Managerial Performance
}

\author{
Sisca Mediyanti ${ }^{1 *}$, Supriyanto ${ }^{2}$, Trie Nadilla ${ }^{3}$, Zahriatul Aini ${ }^{4}$, Agustina $^{5}$ \\ \{*sisca.andra@gmail.com\} \\ ${ }^{1}$ Department of Accounting, Politeknik Kutaraja Banda Aceh, Indonesia \\ ${ }^{2}$ Department of Business Administration, Politeknik LP3I Medan, Medan, Indonesia \\ ${ }^{3}$ Department of Shariah Accounting, IAIN Lhokseumawe, Lhokseumawe, Indonesia \\ ${ }^{4}$ Department of Office Administration, Politeknik Kutaraja, Banda Aceh, Indonesia \\ ${ }^{5}$ Department of Financial Analysis, Politeknik Kutaraja, Banda Aceh, Indonesia
}

\begin{abstract}
This study aims to determine; (1) the effect of TQM implementation on managerial performance; (2) the effect of the reward system on the relationship between TQM implementation and managerial performance; (3) the influence of information technology on the relationship between TQM implementation and managerial performance. Respondents in this study were General Managers, Managers and Field Managers at State Owned Enterprises (SOEs) in Banda Aceh. This is an explanatory research using a sample of 10 SOEs in Banda Aceh and the population techniques. It used multiple linear method. The results of this study indicate that: (1) TQM implementation has an effect on managerial performance. This means that the implementation of TQM has an influence and plays a role in behavior, ways of working and motivation of managers to achieve high performance; (2) the reward system weakens the influence of TQM implementation on managerial performance. The existence of these influences shows that the implementation of TQM and the reward system cannot lead to the creation of high managerial performance; (3) information technology weakens / does not affect the implementation of TQM on managerial performance, this shows that the implementation of TQM and IT is not able to motivate to improve managerial performance.
\end{abstract}

Keyword : Study, Information Technology, TMQ.

\section{Introduction}

The current conditions with an increasingly sharp competitive environment, the demand for the implementation of a clean and authoritative government (good corporate governance), including demands for improvements in public services, increases. For government administrators and public companies (in this case the State-Owned Enterprises), their performance has to improve and continue to grow. Government and state-owned enterprises (SOEs) must have products with better quality and better service compared to their competitors. This means that Government Administrators and State-Owned Enterprises must be able to achieve certain quality levels in all aspects, including product, operating system, and the quality of human resources which cannot be abandoned. This quality system is better known as Total Quality Management (TQM). Based on various experiences of the companies 
that have implemented TQM, it is known that middle level management plays the largest portion of TQM implementation in daily activities. It is often that middle managers function as project team leaders, who are trying to find new ways to do things and new things to do. The success of middle managers in adapting to TQM and their success in carrying out their leadership functions, strongly supports the success of TQM as a whole [1]. Perhaps due to the absence of a reward system, it is difficult to include the criteria and the types of the reward. In the future, a reasonable system, such as rewards realized in the form of incentives, bonuses, etc., can be included, so that the elements of fairness are well developed. The success, progress and level of productivity in organizations are also recognized to be very dependent on information technology support and capability, and supported by a good training system, the quality of human resources and the availability of adequate capital to make important investments in facing the changing trends. Current work patterns and IT support have expanded to the development of products and services, as well as the benefits obtained by management through the ability to access important data at any time. Operational effectiveness, reporting systems and decision-making processes continue to increase, supported by the ease of obtaining references. This reflects the application of IT as a major asset for success, and it is believed that this will continue in the future. In the State-Owned Enterprises operating in Banda Aceh, based on the author's observation through interviews conducted with several Managers, mentioned that TQM that has been implemented in their company has affected managerial performance in the company. Especially through a reward system that is an important target for managers and information technology helps them in making faster decisions. However, they cannot ascertain the extent to which TQM has affected their performance. Total Quality Management or TQM is a management strategy that is shown to instill quality awareness in all processes within the organization. In accordance with the definition of ISO, TQM is a management approach for an organization that is centered on quality, based on the participation of all its members and aims at long-term success through customer satisfaction and provides benefits to all members in the organization and society.

\section{Methodology}

The object of this research is State-Owned Enterprises to prove the hypothesis about the influence of the reward system and information technology as a moderating variable at SOEs in Banda Aceh. The population in this study was all managers of State-Owned Enterprises in Banda Aceh, with considerations namely (1) Managers are executors of top / central management decisions that are able to interact with employees and top management, and (2) Managers who are directly involved with compiled policies by top management. The population used in this study was all Managers of State-Owned Enterprises in Banda Aceh from 10 State-Owned Enterprises that implement TQM. The entire State Owned Enterprises' managers were sampled in the study and the respondents used in the research were 39 General Managers and Field Managers. The framework used in this study can be presented in the following figure :

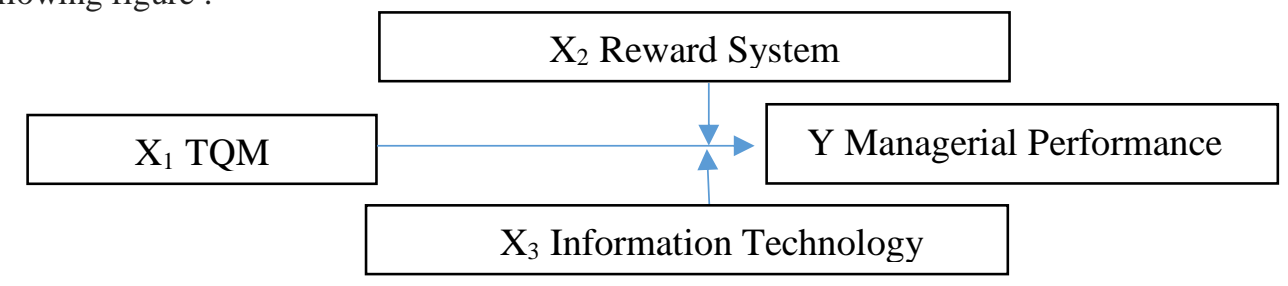


Fig.1. The Framework

Referring to the theory and figure 1, a research hypothesis can be raised, namely the implementation of TQM, the reward system, information technology influences managerial performance in SOEs in Banda Aceh. To see the strength of the influence or relationship between variables is used the criteria proposed by Guildford Criteria [2]. To know the magnitude of the influence of other variables not included in this research model $(\varepsilon)$ is calculated using formula : $\varepsilon=1-\mathrm{R}^{2}[3]$.

\section{Result and Discussion}

Hypothesis testing is carried out after analysis of research instruments and data has been processed. Furthermore, analyzing and testing the hypothesis formulation based on the structure of the relationship model between variables. The regression equation in this case consists of the dependent variable in the form of managerial performance (Y), while the independent variables are: factors consisting of the implementation of TQM $\left(\mathrm{X}_{1}\right)$, the interaction of TQM implementation and reward system $\left(\mathrm{X}_{1} \mathrm{X}_{2}\right)$ and interactions between TQM implementations and Information Technology $\left(\mathrm{X}_{1} \mathrm{X}_{3}\right)$. Based on the data collected using the Statistical Product and Service Solution Program, the results obtained from the analysis of the influence can be analyzed as follows:

Table 1. Results of Multiple Linear Regression Analysis

\begin{tabular}{|c|c|c|c|c|}
\hline \multicolumn{2}{|l|}{ Variabel } & \multirow{2}{*}{$\begin{array}{c}\text { Unstandardized } \\
\text { Coefficient (B) }\end{array}$} & \multirow{2}{*}{$\begin{array}{c}\text { t-count } \\
9,055\end{array}$} & \multirow{2}{*}{$\frac{\text { Sig }}{0,000}$} \\
\hline A & Constant & & & \\
\hline $\mathrm{X} 1$ & TQM Implementation & 0,271 & 1,264 & 0,215 \\
\hline $\mathrm{X} 1 \mathrm{X} 2$ & Interaction between TQM and The reward system & 0,006 & 0,148 & 0,883 \\
\hline \multirow[t]{3}{*}{$\mathrm{X} 1 \mathrm{X} 3$} & Interaction between TQM and The information technology & $-0,012$ & $-0,299$ & 0,767 \\
\hline & $\mathrm{R} \quad=0,431$ & \multicolumn{3}{|c|}{ The number of observation data: 39} \\
\hline & Rsquare $=0,186$ & \multicolumn{3}{|c|}{$\begin{array}{l}\text { Dependent variable: managerial performance } \\
\text { Significant at level } 95 \%\end{array}$} \\
\hline
\end{tabular}

Based on table 1 above, it is known that linear regression can be analyzed based on coefficients. The multiple linear regression equation model based on the table above is:

$$
Y=2,314+0,271 X_{1}+0.006 X_{1} X_{2}-0,012 X_{1} X_{3}+\varepsilon
$$

The results of the regression equation state that the results of the research of each coefficient are for constants $(\mathrm{a}=2,314)$. This means that if the factors of TQM implementation $\left(\mathrm{X}_{1}\right)$, the implementation of TQM with a reward / reward system $\left(\mathrm{X}_{1} \mathrm{X}_{2}\right)$ and TQM implementation with information technology $\left(X_{1} X_{3}\right)$ are considered constant, then the average managerial performance value is 2,314 in the Likert Scale unit or considered performance managerial is close to the normal category.

a. The First Hypothesis testing is done using multiple linear regression or multiple linear regression to test the effect of TQM $\left(\mathrm{X}_{1}\right)$ implementation on managerial performance $\left(\mathrm{X}_{2}\right)$. 
Based on the results of the analysis, the results of $\beta_{1}=0.271\left(\beta_{1} \neq 0\right)$ are obtained. From these results, Ho is rejected and $\mathrm{Ha}$ is accepted. This shows that the implementation of TQM affects the managerial performance.

b. The testing of the second hypothesis also uses multiple linear regression which is done to test the effect of the interaction between the implementation of TQM $\left(\mathrm{X}_{1}\right)$ and the reward system $\left(\mathrm{X}_{2}\right)$ on managerial performance $(\mathrm{Y})$ partially. Based on the results of the analysis obtained the results of $\beta_{2}=0.006\left(\beta_{2}<\beta_{1}\right)$. Based on these results, $\mathrm{H}_{\mathrm{o}}$ is accepted and $\mathrm{Ha}$ is rejected. This shows that the reward system weakens the influence of TQM implementation on the managerial performance.

c. The testing of the third hypothesis using multiple linear regression is done to test the effect of the interaction between the implementation of TQM $\left(X_{1}\right)$ and information technology $\left(\mathrm{X}_{3}\right)$ on managerial performance $(\mathrm{Y})$. Based on the results of the analysis, the results of $\beta_{3}$ $=-0.012\left(\beta_{3}<\beta_{1}\right)$ are obtained. From these results, Ho is accepted and Ha is rejected. This shows that information technology weakens the influence of TQM implementation on the managerial performance

\section{Conclusion}

Based on the discussion in the previous chapter, some conclusions can be drawn as follows: TQM implementation effects managerial performance. This means that managerial in the company is influenced by the condition of the company. The condition of the company is the implementation of TQM which is an approach in running a business that tries to maximize the competitiveness of the company through continuous improvement of products / services, people, processes and the environment. Taking into account the Guildford Criteria, it can be concluded that for the TQM implementation variable on managerial performance of SOEs in Banda Aceh has an influence or relationship that is categorized as low correlation because the value of $\beta_{1}$ lies in $0.20-0.40$. This test is also supported by the results of research by Tersziovski and Samson which concluded that TQM affects managerial performance [4]. The same research was conducted by I Made and Rani in thesis entitled The Effect of Interaction on Managerial Performance (an empirical study at PT. Telkom Divre V Surabaya) in 2003, stating that TQM had a positive effect on managerial performance [5]. The reward system weakens the influence of TQM implementation on managerial performance. This shows that the implementation of TQM and the reward system in the company together can reduce the influence on managerial performance. By paying attention to the Guildford Criteria, it can be concluded that the influence variable Interaction between TQM implementation and the reward system for managerial performance in the SOEs in Banda Aceh has an influence or relationship that is categorized into negligible relationship because the value of $\beta_{2}$ is smaller than 0.20. Information technology weakens the influence of TQM implementation on managerial performance, this shows that the implementation of TQM and information technology in the company together does not affect managerial performance. By paying attention to the Guildford criteria, it can be concluded that information technology weakens the influence of TQM implementation on managerial performance of SOEs in Banda Aceh, the effect is inverse or negative. 


\section{References}

[1] F. Tjiptono and A. Diana, Total Quality Management. Yogyakarta: Andi, 2003.

[2] J. P. Guilford and B. Fruchter, Fundamentals Statistics in Psychology and Education, 5 th. New York: McGraw-Hill, 1973.

[3] H. J. Loether and D. G. McTavish, Descriptive and Inferential Statistics: An Introduction, 4 th. Singapore: Allyn and Bacon, 1993.

[4] D. Samson and M. Terziovski, "The Relationship Between Total Quality Management Practices And Operational Performance,” J. Oper. Manag., vol. 17, no. 4, pp. 393-409, 1999.

[5] I. M. Narsa and R. D. Yuniawati, "Pengaruh Interaksi Antara Total Quality Management Dengan Sistem Pengukuran Kinerja Dan Sistem Penghargaan Terhadap Kinerja Manajerial Studi Empiris Pada Pt. Telkom Divre V Surabaya,” J. Akunt. dan Keuang., vol. 5, no. 1, pp. 18-34, 2003. 